STUDIA UKRAINICA POSNANIENSIA, vol. II: 2014, pp. 147-156.

ISBN 978-83-936654-5-7. ISSN 2300-4754.

\title{
ПРИВАТНИЙ АПОКАЛІПСИС: ДО І ПІСЛЯ (ЗА РОМАНАМИ ТРАКТАТ ПРО ЛУСКАННЯ КВАСОЛІ ВЕСЛАВА МИСЛИВСЬКОГО ТА ХУТІР АНДРІЯ КОНДРАТЮКА)
}

\author{
ТЕОДОЗІЯ ЗАРІВНА \\ Національна спілка письменників України, Київ - Україна \\ PRYWATNA APOKALIPSA: DO I PO \\ (WEDŁUG POWIEŚCI TRAKTAT O ŁUSKANIU FASOLI WIESŁAWA \\ MYŚLIWSKIEGO I POWIEŚCI CHUTOR ANDRIJA KONDRATIUKA) \\ TEODOZJA ZARIWNA \\ Narodowy Związek Pisarzy Ukrajiny, Kijów - Ukraina
}

STRESZCZENIE. W artykule dokonana została analiza tragicznego doświadczenia głównych bohaterów dwóch powieści na tle historii wschodnioeuropejskich społeczeństw totalitarnych XX w., doświadczenia, urzeczywistnionego w nowatorskiej formie współczesnej prozy.

\author{
PRIVATE APOCALYPSE: BEFORE AND AFTER \\ (BASED ON THE NOVEL A TREATISE ON HUSKING OF KIDNEY BEANS \\ BY WIESŁAW MYSLIWSKI AND ON THE NOVEL THE FARM \\ BY ANDRIJ KONDRATIUK) \\ TEODOZYA ZARIVNA \\ The National Writers' Union of Ukraine, Kyiv - Ukraine
}

ABSTRACT. The article analyzes tragic the experience of the two novels' main protagonists. This experience is presented against the backdrop of the history of East Europe totalitarian societies of the $20^{\text {th }}$ century. It has been incarnated in the innovative form of modern prose.

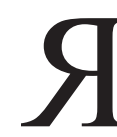

кщо дві чималі книги: роман Хутір Андрія Кондратюка нараховує 850 сторінок, роман Трактат про лускання квасолі (Traktat o tuskaniu fasoli) Вєслава Мисливського - 400 - уявити двома фільмами і накласти плівку на плівку, відбудеться дивна річ, оскільки вони показуватимуть дуже синхронну історію. I хоч вона не буде подібною у деталях, проте в головному часом разюче збігатиметься. Треба зазначити, що не йдеться про якісь взаємовпливи, бо обидва автори навіть не здогадуються про власне обопільне існування. Йдеться про якісь подібні схеми людського життя у тоталітарну і посттоталітарну добу, про певну притчевість і узагальненість існування малої людини в агресивному світі. Людини, яка пережила трагедію. 
Вєслав Мисливський - відомий і шанований польський прозаїк. Його перу належать романи Голий сад (Nagi sad, 1987), Палаи (Pałac, 1970), Камінь на камені (Kamień na kamieniu, 1984), Виднокруг (Widnokrag, 1996), Tрактат про лускання квасолі (Traktat o tuskaniu fasoli, 2006, 2010), Остання роздача (Ostatnie rozdanie, 2013). Він двічі отримував премію „Ніка”, переклад його книги Камінь на камені (Stone upon stone, 2010) був відзначений престижною нагородою в Америці: Best Translated Book Award for fiction (перекладач Білл Джонсон). Популярний тижневик „Publishers Weekly” відмітив, що Камінь на камені є першим слов'янським шедевром. Про книгу захоплено писали „Times Literary Supplement”, „The National”, „The New Yorker” та інші ${ }^{1}$.

У Андрія Кондратюка літературна доля суворіша. Він найкращу частину свого життя був відсунутим на маргінес літературного життя з ідеологічних мотивів. Перший роман Дорога до матері (2009) вийшов друком аж через 23 роки після написання. Серед багатьох книг прози автора роман Хутір (2005) $\epsilon$, на наш погляд, найважливішим твором письменника. Він висувався на здобуття національної премії ім. Тараса Шевченка, отримав премію Благовіст. Звичайно, як людина цілком непублічна, автор не має розголосу, на який претендував, але своїм письмом впливав на літературу, а його роман вартує уважного прочитання.

Про Андрія Кондратюка писали Павло Загребельний, Олесь Ульяненко, В'ячеслав Медвідь, Степан Сапеляк та інші ${ }^{2}$.

Майже всі вони письменники. Письменник мимоволі аналізує текст зі середини, його цікавить практична рецептура твору і причина емоційної реакції реципієнта, в даному випадку, власна.

Автор, зазвичай, або знає фінал і під нього „підганяє” все викладене, або усім матеріалом, яким він поступово обростає, шукає цей фінал. Матеріал дуже часто прямує до трагедії. Виходячи із психології творчості, наявність трагічного як факту людського життя і відображення його у жанрі літературного

J. C r o f t, Stone upon stone by Wiesław Mysliwski, [online:] http://quarterlyconversation. com/stone-upon-stone-by-wiesaw-mysliwski; G. D a w s o n, A rumbunction and charming examination of the life of a farmer in postwar Poland, [online:] http:/www.amazon.com/Stone-UponWieslaw-Mysliwski/product-reviews/098262462X/ref=dp_top_cm_cr_acr_txt?showViewpoints=1; A. H e n r y, "Stone Upon Stone" by Wiestaw Myśliwski [25 Days of the BTBA], [online:] http://www.rochester.edu/College/ translation/threepercent/?id=3856; N. M a r c h, Wieslaw Mysliwski's new country for old men, [online:] http://www.thenational.ae/arts-culture/books/wies-awmysliwskis- new-country-for-old-men; Kaija Straumanis, Stone upon stone by W. Mysliwski, [online:] http://www.rochester.edu/College/translation/threepercent/index.php?id=3398; D.R. M o r r i s, A masterful epic about rustic life in $20^{\text {th }}$ century Poland, [online:] http://www.amazon. com/StoneUpon-Wieslaw-Mysliwski/product-reviews/098262462X/ref=dp_top_cm_cr_acr_txt? showViewpoints=1

2 Див.: Т. 3 а р і в н а, Непрочитаний епос, [в:] „Кур'єр Кривбасу” 2011 , № 258, с. 363-365; В. М е д в і д ь, Люди зі страху, [в:] „Українські проблеми” 1997, № 1, с. 151-153; С. С а п е л я к, Щоб минуле не щзезало, [в:] „Київ” 2006, № 10, с. 176-178; О. У л ь я н е н к о, Брак культури породжує брак совісті, [в:] „Робітнича газета” 1997, № 124. 
твору вимагає великої відваги від автора. Як правило трагедії пишуть автори молодшого письменницького віку у 30-40 років, котрі мають про них, здебільшого, чисто теоретичне уявлення, або ж письменники старшого покоління, котрі можуть вже до певної міри відштовхуватися від власних трагедій і від усвідомлення їх у суб'єктивному досвіді, відсунувши певний екзистенційний страх перед наслідком моделювання трагічного у слові. Відмівши всі заборони і всі табу, які може виставляти літературна ситуація чи власна внутрішня цензура, автор раптом усвідомлює, що за ним - довге складне життя, яке вже на всі слова дає право. Тож дочекавшись того короткого періоду, коли ще можеш говорити і вже знаєш, що мусиш сказати, він зважується написати твір, котрий має далеко інші смислові виміри й дещо інше емоційне наповнення.

Але якщо він пише за трохи іншими законами, аніж закони ринку, і пам'ятає, що за якими законами пише, за такими судять, автор швидше за все утримається від спокуси моделювати світ нібито власної трагедії, аби не накликати щось із витвореного на себе або ж майстерно відводитиме події від проекції через себе. При цьому твір завжди щось втрачає.

Звичайно, можна присвятитися більш благополучній драмі, яка не змушує до кровопролиття у творі і дає багато можливостей для закодовування власного досвіду, для переповідання більш-менш спокійних історій, не надто надриваючись нервово зайвий раз між чергуванням доброго і злого у творі (вистачить його і в реальному житті). Але нерідко саме на схилку віку талановитий автор пише книгу як останню, де його власний досвід набуває універсальності, притчевості, котра лягає на трагічний досвід читача, ніби рамка на картину, і вони разом створюють знаковий твір, що вражає.

Інколи таке письмо, „сильне і страшне” (як писали про Стефаника) виходило і в молодих. Фолкнер говорив, формуючи свій список кращих письменників: „Перший - Томас Вулф, має неабияку відвагу і пише так, ніби йому вже недовго жити...”, що і сталося, бо невдовзі Вулф помер від ускладнень грипу у тридцять $з$ чимось років. І ось цього „що і сталося”, незбагненного і непоясненного, всі і побоюються.

Два твори, про які піде мова, - це великі епічні романи, котрі написали мудрі і літні автори, молода людина їх просто не напише через брак певного досвіду. Обидва письменники відображають не стільки село, скільки людину на тлі села, котре зникає разом зі своєю великою і предковічною культурою. Вони, безумовно, усвідомлюють значення трагедій, що відбувається з їхніми героями, для свого потенційного читача, котрий переживав приблизно те ж саме. Одна і та ж трагедія - життя у тоталітарному суспільстві - розгортається у різній множинності історій, котрі трапилися у різних країнах, але які і зовнішньо, і внутрішньо, за емоційним наповненням, дуже схожі.

\footnotetext{
${ }^{3}$ У. Ф о л к н е р, Анекдоты и факты биографии, вып. 8: Исторические анекдоты от Старого Ворчуна, (ред. В. Киселев), [электронний ресурс:] http://holit-i-leleyat.livejournal.com/ 50492.html?thread=1288764
} 
Хутір у Андрія Кондратюка (чи колишне село у Вєслава Мисливського) - це рай на землі, рай, де всі ще разом, де гуртом тереблять квасолю, де світиться лампа, як предмет, який об'єднує, де ніхто не страшний, бо сім'я - це сила, бо спокій стережуть святі скульптури, вирізьблені із дерева чи дев'ять биків перед брамою, котрі зі страшним ревом кидаються на незнайомців, поряд ще живі брати і коні, безцінні книги і безмежне пасовище, де первісний спокій і дівчинка в червоному від весни до осені, де тече ріка і в ній відбивається небо. Руйнування цього раю і означає руйнування всесвіту.

Лускання квасолі - залишок того життя, котре знищили, залишок, на який однак ніхто не зможе посягнути, бо він у пам'яті. А пам'ять - це окрема резервація безсмертя. Це те, що найдорожче, тому і головне: „I gdyby pan mnie spytał, czy byłem kiedyś szczęśliwy, to jedynie wtedy"4.

Якщо у романі Вєслава Мисливського трагедія відбудеться майже на початку, а всі події після неї поволі гасять іï шлейф і наслідки, то у Xуторі все готує трагедію, починаючись 3 високої точки щастя і обвалюючись у страшне неухильно і невпинно. Це невмолимий фатум. Його не обминути. А трагедія полягає в тому, що одного дня приїдуть люди у формі і спалять село, розстрілявши всіх його жителів (Трактат про лускання квасолі), або ті ж люди у формі розстріляють дев'ять биків найбільшого і найнепоступливішого господаря у хуторі, аби змусити до колективізації і розтягнуть трагедію на кілька десятиліть (Хутір), протягом яких рай стане пусткою, розвалиться, допоки не зникне з лиця землі повністю. Авторам вистачає дихання, аби цей дух трагедії витримати протягом усього твору в епіцентрі напруги.

У Трактаті про лускання квасолі все, що трагедія залишила, окраденого і зламаного ще в зародку, за формою - ще життя, насправді ж, у ньому практично панує пустка, незважаючи на всі зовнішні ознаки нормально перейденого героєм віку. У романі Вєслава Мисливського за одну мить у селі залишиться лиш хлопчик, якого мама послала до льоху за буряками, і лиш дивом дивним його не застрелив універсальний чоловік у формі, розрядивши набої у незвичайну багатолітню майже безсмертну свиню, котру чимало років батьки хлопчика так і не змогли зарізати з огляду на незвичайну поведінку тварини (може, то не свиня, а знак, - витлумачить іiї дії сільський мудрець - не знаю, я не ребе, я - лиш фактор), саме вона ходила за хлопчиком скрізь: і до магазину, і до церкви, і зрештою, відчувши, що він у льоху, не відходила від лазу, прийнявши його смерть на себе. I хлопчик, ставши літньою людиною, врешті розповість таємничому незнайомцеві про те, що з ним сталося і яким трибом пішло його середньостатистичне людське життя після такого початку.

У Трактаті про лускання квасолі господар розповідає невідомому гостеві своє життя. Чому вибрав саме цього гостя? Може тому, що той мовчав і слухав, може, навіть хотів купити квасолю. Ми цього достеменно не знаємо. I дуже може статися, що він це говорить у вічі власній смерті і навіть пом'якше-

${ }^{4}$ W. M y ś 1 i w s k i, Traktat o łuskaniu fasoli, Kraków 2010, s. 14. 
ний фінал, який не стверджує нічого напевно, може стверджувати і це. Господар іде на вечірній огляд будиночків, навіть гість не перебив його щоденного ритуалу. Вперше без псів, лишаючи їх на незнайомця. Не вгадати, чи надовго. Тут так і проситься крапка. Але їі чомусь не буде. А буде три крапки. Видатний польський критик Генрик Береза писав про цей твір:

Як і кожен шедевр - це, передусім, велика таємниця мистецтва, щось незбагненне, котре, здається, з'являється з іншого виміру ${ }^{5}$.

В обидвох романах спосіб вислову не дуже зважає на романну моду нашого часу, навіть навпаки, свідомо виступає проти усякої моди. Але це не каприз літнього автора, а усвідомлення своєї сили, а також мимовільного поборення чергової моди (в обидвох випадках це відбудеться з успіхом). I там, і там - ілюзорна відсутність класичного сюжету у стандартному розумінні: зав'язка, хід подій, кульмінація і розв'язка. Ясна річ, він присутній, і майстерно замаскований. В обидвох випадках мова йде від першої особи. А зважаючи на розмір роману Хутір у 850 сторінок, здавалося б, як втримати читача, досвідченого, спокушеного класикою і сучасним різноманіттям, таким розміром. Але обидва тексти дуже добре тримають читача у напрузі, використовуючи динаміку думки, почуття, розвитку образу.

I там, і там розповідь від першої особи. Розповідь в обидвох випадках класично-спокійна, посттрагічна, розповідь, яка використовує новітню стилістику: не боїться довгот, навпаки, свідомо їх використовує. Безконечно-викличний опис блискучого імпровізатора Вєслава Мисливського у сцені вибору капелюха як одного із символів вищості, панськості і обраності, котрий герой побачив вперше у німому фільмі в дитячому будинку, або ж предовгий опис героїв хутора із їхніми майже житіями за каноном біблейським у романі $X y$ mip, де і святі, і грішні, мовби задані якоюсь вищою метою, переплавились у спільному сільському взаємоіснуванні. Може, світ і не пропав би без того чи іншого героя, але він був би значно бідніший і простіший, здається, говорить автор. Чи є щось у світі, що після трагедії героїв має значення? В обидвох романах - це місце, місце, яке тягне свідомо чи підсвідомо. У польському романі герой повертається із Америки, де мав добру роботу і непоганий побут. Повертається наче й несподівано, наче на випадкову репліку випадкового друга, котрий пише до нього листи з батьківщини. В українському - він повертається зі столиці, бо без цього куточка вже не мислить свого існування.

${ }^{5}$ H. B e r e z a, Czytam, wiec jestem, [online:] http://wyborcza.pl/1,76 842,8811447,Bereza _Czytam_wiec_jestem.html; J. C h $\nmid$ o p e k, Odkrywajac sens istnienia świata, [online:] http://www.znak.com.pl/kartoteka,ksiazka,680,Traktat-o-luskaniu- fasoli\#materials; K. D ą b r o w $\mathrm{s} \mathrm{k}$ a, Wiesław Myśliwski - sylwetka twórcza, [online:] http://culture. pl/pl/tworca/wieslaw-mysliwski http://culture.pl/pl/tworca/wieslaw-mysliwski; E. L e w i c k a, O kulturze życia z Wiesławem Myśliwskim, [online:] http://www.biznesistyl.pl/ludzie/wywiady/102_o-kulturze-zycia-z-wieslawemmysliwskim.html; K. S t e r n a $1 \mathrm{~s} \mathrm{k} \mathrm{a,} \mathrm{Nieznajomy,} \mathrm{[online:]} \mathrm{http://www.znak.com.pl/kartoteka,}$ ksiazka,680,Traktat-o-luskaniu- fasoli\#materials 
Чи було це випадком, чи закономірністю - весь час ставить собі запитання Вєслав Мисливський, і наскільки випадком? Філософ Мераб Мамардашвілі говорить: „Ми самі - істоти, для випробування створені, і лиш ризиком існуємо абсолютно без будь-яких гарантій”б. Автор однак не дає відповіді. Він дає лиш вервицю фактів, із яких складається життя його героя.

Коли у Xуторі панує наївний дитячий погляд на світ, до кінця не вбитий подіями біографії (це вбивство повільне і не менш жорстоке), його трохи скрашує життя матері і батька, родини (яка поступово втрачає своїх членів у енкаведистських стінах чи зачистках і якої герой Трактату про лускання квасолі позбавлений одразу і навіки), а бар'єр між стражданнями і особистістю був дещо товщим через оцей родинний захист, то у Трактаті вага травми від дій тоталітарного режиму жорстоко вражає дитину і деформує ще у ранньому дитинстві, практично знищивши іiі внутрішньо, залишаючи ій холодний і підозріло-спокійний, безпристрасно-вичахлий і все-таки живий погляд. В. Соловйов сказав, що „держава потрібна не для того, аби створювати щастя, а щоб не було пекла" ${ }^{\text {. }}$ На жаль, в обидвох романах торжествує державне пекло. Герой Трактату - зовні абсолютно нормальна людина, щоправда, тільки не хоче мати дітей і володіє якимось надприроднім потягом до порядку, так начебто працював колись у концентраційному таборі. Звісна річ, він у ньому ніколи не працював, вистачило лишень жити у дитячому повоєнному будинку. Заглядаючи у дитячий будинок Мисливського, кров холоне у жилах - i в його жителів, і в читачів. Ось один приклад - хлопці грають у сірнички. Хто програє (а програє лишень один, хто грає найгірше), з тим можуть робити все, що заманеться. Можна уявити, що означає „що заманеться”, якщо всі, хто програє, одразу починають плакати, а один із невдах навіть скочив до вуличного вигрібного туалету, аби пройнятися його запахами надовго, хай гидують до нього торкнутися. Але його не рятували, чекали доки рівень фекалій дійде до шиї, потім до рота (хай нажереться, якщо такий хитрий), тоді до чола, і аж після цього витягали за чуба. Такий собі варіант забруднення життям. До речі, у сірнички герой грає наприкінці із таємничим незнайомцем і всі рази програє, правда не визначено лише плату. Одна із можливих варіацій - це гра на життя.

Були й інші забави - спроба повісити вчителя як бунт проти того, що виключили світло саме на перегляді фільму, вчителя, абсолютно не винуватого у пригоді, вчителя-символа, вчителя, який приніс у їхне життя високу музику, бо організовував оркестр. Може, саме такі забави позбавлять героя вміння любити (собаки, яких він обожнює, у рахунок не йдуть, мова про людей) у житті. Адже була жінка, котра його кохала, але покинула. Може, через те, що не хотів мати дітей. Чи не досить було їх для нього у дитячому будинку?

В обидвох романах герої наприкінці власного життя - „сторожі покинутого раю” (послуговуючись назвою власної поетичної книжки). Герой Хутора

\footnotetext{
${ }^{6}$ М. М а м а р д а ш в и л и, Мой опьтт нетипичен, Санкт-Петербург 2000, с. 303.

${ }^{7}$ Там само, с. 287.
} 
сторожить місце і пам'ять, так само і герой Трактату про лускання квасолі сторожить місце і пам'ять (ті дачні садиби, які постали на території його села і в яких живуть час від часу, в залежності від сезону). Кращих сторожів - не знайти. У кожного з них власні методи. У романі Мисливського музикант, незламний у своїх переконаннях, доглядає педантично і вперто будинки і... могилки. Він саме перемальовує імена на табличках, котрі стер вітер, сніг і дощі. I лишень час від часу оживає його душа, коли бачить можливість поправити справедливість: врятувати побиту жінку, котру викинув деспот-коханець, чи собаку, яку хазяїн зібрався втопити, або ж коли згадує музику - ту силу, заради якої жив і завдяки якій вижив (мотив саксофона проходить крізь увесь твір, він віртуозно описаний автором - саме бажання мати саксофон, і регулює дії героя, веде його шляхом, що спрямований на збереження життя людини, на відродження у світі знищеного смислу; однак доля послала йому запалення суглобів і неможливість грати, і знову цей смисл відсувається, як горизонт). У Хуторі ж герой вперто реставрує власну садибу, понищену холодом і людьми, і тримають його серед безнадії книги. Книги, які становлять найбільшу цінність героя. I тому момент, коли герой побачив лиш купку попелу замість полишених книг, а у стародавній, ще батьківській криниці - перевернутий виходок з усіма екскрементами, знаменує закінчення трагедії, яка розтягнулась у часі на тривалість людського життя і яка теж почалася від людей у формі, котрі розстріляли биків, полишивши з того часу хутір міченим, і врешті завершилась уповні.

Якщо Хутір - більше національна ламентація плюс медитація, то Трактат про лускання квасолі - більше національна медитація плюс ламентація.

У романі Мисливського людина у формі, що брала участь у знищенні села, накладає на себе руки. У Хуторі ж людина у формі отримує завдання знищити сто повстанців, тоді йому вибачиться співробітництво з німецькою поліцією. Він не дотягує до ста, бо знищив 99 (здебільшого, безневинних, зайнятих роботою на полі, аби швидше сягнути обіцяної цифри), проте спокійнісінько живе собі серед людей, ніхто йому навіть поганого слова не скаже і не докорить аж до самої смерті. Велика сила людського милосердя. I чи це вже милосердя?

Якщо Трактат про лускання квасолі - строго лінійна історія однієї людини, то Хутір - велетенська мозаїка, виповнена житейськими історіями земляків героя із неймовірно гарного поселення Наталія. Це сага про їхнє життя на землі, із народженнями, весіллями, болячками і смертями, об'єднана літнім героєм, який ранньої весни приїжджає зі столиці до батьківської хати, котра дивом заціліла на місці колишнього хутора, живе до пізньої осені, а потім усю наступну зиму з великим страхом очікує вістки про іiї знищення. I там, і там - амплітуда людських чуттів і мандрів - у Трактаті від погреба до американського ресторану і способу життя, а потім знову на дно навіть не села, а примари колишнього села, де доводиться стати побережником і до певної міри реставратором колишнього існування. Герой Хутора теж реставратор 
минулого - від хати аж до історії спаленого села. Що дуже важливо, спільної і впізнаваної історії.

Чому український роман названо Хутір - ясно: це те, що він хотів описати і залишити у людській пам'яті, протистоявши знищенню і забуттю. А от чому трактат?

Можливо, філософський трактат написати легше, аніж трактат про лускання квасолі, котрий є вищим і дорожчим, за всі великі розумування. Адже після минулого життя у „романтично переуявленому дитинстві”, героя лишився напам'ять тільки один безцінний епізод - родина лущить квасолю у світлі гасової лампи. Ця ясна картина буде супроводжувати його усе життя як своєрідне підключення до певного енергетичного джерела, до біблійного образу святої родини, котру відібрали насильно з фізичного існування, але не ідеального, не $з$ життя духа.

Чому ці дві трагедії такі промовисті? Тому що кожна із них вигранила особливу форму, потвердивши давню тезу про єдність форми і змісту. У Мисливського - монолог практично без партнерів, хоча ніби він і говорить 3 гостем, але говорить без діалогів, заперечуючи саму традиційну прозу, котра населяє твори людьми, які безперестанку говорять. Тут чути тільки один голос, таке собі неспішне відчайдушне соло. Всі відповіді свідомо випущені.

Нове у тлумаченні природи самого життя - агресивний випадок, котрий міняє напрямок людського існування, яке постійно балансує на грані між випадком і закономірністю. Нове - теми, здавалося б, непідвладні прозі, оспівати неоспівувані речі - саксофон, капелюх, його примірювання (дві сцени - у фільмі і в магазині), оспівувати неймовірно довго, віртуозно, ризикуючи втратити міру і не втративши іï.

Своєрідна стилістика твору і у Андрія Кондратюка. Мова, яку не часто зустрінеш в українській літературі - сплав поліського діалекту, інколи на межі з грецьким гекзаметром, якоїсь казки-народної оповіді із доволі значними періодами - неможливо вичленити щось для ілюстрації - все одразу розсипається. Створюється враження, що мова роману - живий організм, скромний, несміливий, делікатний, як і богобоязлива авторська манера подачі матеріалу - дуже лагідними та обережними мазками про страшні і жорстокі речі - і на контрапункті виходить ще страшніше. (Тут слід згадати ще один визначний роман, написаний на поліському діалекті, неперекладний і неперекладений, Листя землі (1990) Володимира Дрозда, велику епопею про XX українське століття, страшне і криваве - від початків радянського ладу аж до його закінчення).

Масштаб зображуваного (все двадцяте століття, котре пройшлося потоптом по його землі), сплавлений з авторськими відступами, роздумами, цитатами, віршами у Xуmopi, із його агресивним ставленням до людини - у романі Трактат про лускання квасолі. Але масштаб зображення - це, швидше, міра таланту.

\footnotetext{
${ }^{8}$ Б. Р у б ч а к, Міти метаморфоз або пошуки доброго світу, Львів 2012, с. 479.
} 
Прикметно, що обидва автори ніде не нарікають на тих, що створили їм таке життя, на систему чи час, не аналізують, хто в усьому винен. Ворога ніби i не існує, його перепроваджено до Божого суду. Християнська віра допомагає жертвам лишатися людьми. Це не означає, що вони обидва - глибоко релігійні (у Xуторі все пронизано ледь чутною, але глибокою вірою) у Трактаті про лускання квасолі про це практично ні слова. Минуле витерто з погляду на світ і, може, вперше проривається у словах, звернених до таємничого гостя.

Якщо у героя з Хутора є ще куди повертатися, але страхом, яким пронизане це повернення - приїхати і побачити руїну, - просякнуті всі роки, котрі він зимує у місті, а літує вдома, неймовірний тягар не надто й прозірливого передбачення (всі інші хати на хуторі давно поруйновано), що його територія уже також в руїнах, тримає його підвішеним між землею і небом кожну чергову зиму у далекій столиці, то герой Мисливського пильнує порядок речей, він не може допустити руїни, на його колишній території життя відновилося, до певної міри і завдяки йому, і хоч воно курортне, епізодичне, проте не вбивче. Однак сам Вєслав Мисливський у документальному фільмі Місия, котрих немає (Miejsca, których niema, 2002) говорить:

Не вірю у сентиментальні зв'язки з місцем народження, я цього місця боюся. Ніде так не боюся, як у тому своєму ліричному раю9.

Бо він там час від часу бачить зруйнований родинний дім, повибивані шиби, ниючу пустку. Це автор чомусь у роман не впустив. Життя однакове скрізь під цим спільним небом.

Маленька людина у крихітному місці на карті - „у кінцевому рахунку все, що діється в будь-якому куточку світу і в будь-якій спільноті, є складником світового життя, його поширює, варіує і деталізує, і вже тому варте уваги і поцінування" 10 .

I там, і там, література, що виростає до міфу - і першою особою-наратором, і впізнаваністю ситуацій та образів, і мовою про сакральне, святе, що дає сенс людському буттю: земля, якою опікуються, християнська чи людська мораль, сім'я і ії вага у людському житті, авторитет батька, хліба, духу, традиції.

Обидва твори не дуже турбуються про читача. У них нема тієї інтриги, яка, здебільшого, присутня у сучасних романах. Вони дуже великі за обсягом, багатослівні і описові. Вони - наче суцільний виклик сучасній літературі. Генрик Береза писав:

${ }^{9}$ W. M y ś 1 i w s k i, Miejsca, których nie ma, [online:] http://www.filmpolski.pl/fp/ index.php/4219406

${ }^{10}$ I. Д $з$ ю б а, Марко Павлишин: крізь „постмодерністські окуляри” і без них..., [в:] М. П а в л и ш и н, Канон та іконостас, Київ 1997, с. 6. 
Вєслав Мисливський своєї письменницької енергії не дрібнить, не залежиться йому, можна припустити, на iï постійній експлуатації, йому йдеться лиш про своєрідне iї виверження ${ }^{11}$.

Якщо вертатися до фільмів, то фільм Мисливського - чорно-молочний, у айтматівських туманах, з додатком світел чи вогників на дні ночі, а фільм Кондратюка - кольоровий, із його райськими барвами наприпочатку і вибляклістю, як на стародавніх іконах, наприкінці. Якщо у Трактаті про лускання квасолі переважають повільні панорами і крупні плани, то у Xуторі - кліповий монтаж із окремих життів кожної родини і, здебільшого, загальні плани.

„Трагедія - улюблений жанр історії, - говорив Йосиф Бродський. - Якби не властива літературі витривалість, інших жанрів ми і не знали б, жанром як постійним дотягуванням до життя і скористались уповні Вєслав Мисливський і Андрій Кондратюк. Трагедія проступає крізь тексти їхніх творів, як кров крізь бинт, і надає кожному з них античної масштабності і екзистенційної невідворотності.

\footnotetext{
${ }^{11}$ H. B e r e z a, Twórczość, [w:] W. M y ś 1 i w s k i, Pałac, Kraków 2010, na okładce.

${ }^{12}$ И. Б р о д с к и й, Поклониться тени, Санкт-Петербург 2006, с. 47.
} 